\title{
Contribution of "Abolishment of Serf System" in Tibet to Human Rights Campaign \\ ---- In Memory of the Fiftieth Anniversary of Democratic Reform in Tibet
}

\author{
Li Sha \\ Department of Social Sciences, Shenyang University \\ E-mail: syhgs12@163.com
}

\begin{abstract}
In 1959, the Chinese government conducted a democratic reform in Tibet, and thoroughly abolished feudal serf system. Feudal serf system in Tibet before that time was dark and ferocious, vandalizing "human character, personality, human rights and humanity", seriously obstructing overall progress of the Tibetan society, and isolating Tibet from the modern civilized world. The fact in Tibet that "millions of serfs acquired freedom and liberation, and thence became human in its actual meaning" was in line with the goal of human rights campaign without doubt. Therefore, the Chinese government and people made another great contribution to the human rights campaign and human civilized progress.
\end{abstract}

Keywords: Abolishment of serf system, Human rights campaign, Contribution of China

On December 10, 1948, the General Assembly passed "Universal Declaration of Human Rights". This historically meaningful declaration provided a reference to all countries for their reflection of human rights condition and human rights career.

On October 1, 1949 when the new China was founded, the Chinese people broke away from a fate of being oppressed and enslaved, acquired freedom and liberation, and possessed their rights to freely survive and develop. However, the old Tibet of China in the 1950s was still in a developmental stage of feudal serf system. The situation of the dark politics, depressed economics, out-dated culture, and hard livelihood in Tibet was ghastly. The huge number of serfs was regarded as "critters that could speak" and "tools that could speak", and they had no "dignity and rights of humans". The old Tibet was dissociated far away from the modern civilized society, so it was called "the last relict medieval solitary island" in the modern civilized world of the $20^{\text {th }}$ Century.

In 1959, in compliance with will of all Tibetans, the Chinese government conducted a democratic reform in Tibet, and thoroughly abolished the inhuman feudal serf system which had reigned Tibet for several hundred years. Millions of serfs in Tibet acquired freedom and liberation in terms of politics, economics and spirit. Thence, they broke away from the ruling chain, owned "dignity and rights of human being", became "human in its actual meaning" for the first time, and became a master of their own fate and the Tibetan society. The democratic reform of "abolishment of serf system" in Tibet was the most glorious and magnificent Psalms in the history of "abolishment of serf system", and was another great contribution of Chinese government and Chinese people to the human rights campaign and human civilized progress.

The reason why the Chinese Central Government conducted the democratic reform in Tibet and abolished the serf system mainly contained the following two.

\section{1. "Vandalization on people" of Tibetan feudal serf system}

The first article in "Universal Declaration of Human Rights" stipulated as follows "Every one is born free, and is equal in dignity and rights without exception. They are endowed with rationality and conscience, and they treat each other like brothers." The fourth article stipulated as follows "No one should be treated as a slave or be slaved. Any form of slavery or slave transaction should be prohibited." In consideration of the basic content of this declaration, we discover that the 
old Tibet was worlds apart from the social reality. "Even if the jokul turned out to be ghee, it would be owned by the seigniors; even if the river turned out to be milk, we wouldn't drink even a little. Although our lives are owing to our parents, our bodies are possessed by the feudal officials." This Tibetan folk song gives a vivid and accurate description of expropriation of capital goods and labor achievements of serfs by Tibetan serfowners, and a description of infringement of their freedom and dignity.

Feudal land tenure and serfs were attached to personal occupations of serfowners, which was the ruling foundation of feudal serf system in Tibet. Before the democratic reform in 1959, the three major seigniors in Tibet, namely, feudal officials, lords and temple monks, occupied all Tibetan land, including arable land, pasture, forests, wasteland, mountain ranges, and rivers, etc. There was almost three million Tibetan Gram (15 Tibetan Gram equals to one hectare) of tilled land, among which feudal regimes occupied $30.9 \%$, lords occupied $29.6 \%$, and temples occupied $30.5 \%$. There were a couple hundred of lords in Tibet, and more than 20 major serfowners, among which 7 or 8 serfowners were the superior, each occupying dozens of manors, and up to 10 thousand Tibetan Gram of land. Those feudal seigniors, who accounted for only about $5 \%$ of the population, not only possessed all land, but controlled the political power, army and all reigning machines for maintaining their class interests, while those serfs and slaves who accounted for $95 \%$ of the population had no land or personal freedom, and were attached to "the three major seigniors". The latter had no rights to be human, and were not treated as independent humans. They had no choice but to work day and night for their serfowners like creatures, and were fed up with oppression and humiliation. The former Tibetan government stipulated that, serfs had to be fixed on the manor land of those seigniors they were attached to, they were not allowed to leave without permission and were absolutely prohibited to escape.

Tibetan serfs and slaves were classified into three hierarchies, namely, "Khral-pa", "Dui-chun" and "Lang-sein". "Lang-sein" referred to slaves, who had no capital goods, and worked for serfowners for nothing. They were private property of their owners because they were occupied by them all their life and were dominated by them at will. They might be resold, mortgaged, given as a present, and granted at will. If they fled and were caught, they would be beaten up, and some even were beaten to death. These "Lang-seins" accounted for approximately 5\% of Tibetan population, and most of them were passed down from generation to generation. The total household of "Dui-chun" was almost one third of that of serfs, but their population was relatively small. They had no land, and a large majority of them lived their lives as a helper or by selling some handmade articles with an extremely difficult life. "Dui-chun" also had their seigniors. Even if they drifted to other foreign lands, they would have to contribute a poll tax to their seigniors, and even those mendicants would not be exempted. That is to say, each person has his "personal root". Serfs were attached to serfowners together with land, each serf having his master, and shouldn't break away from their serfowners all their generations. "Khral-pa", namely serfs, had some production materials, while slaves hadn't. Serfowners classified his land occupied into two types, one called "self-support land" and the other called "copy land". "Self-support land" was possessed by serfowners, while "copy land" was allocated to their slaves for plough. With "copy land", a slave then was a serf, who got the land on the condition that he provided definite objects, monetary and service. Labor services of Tibetan serfs had two types, of which was "external service", a service for the nation and the government, such as use of grain by chancellors and yamun in Tibet, and magic flask lama service, etc. On one hand, seigniors and feudal officials ordered their serfs to send such definite objects as grain and ghee plundered everywhere back to their official locations station by station. On the other hand, they used definite objects captured outside for business trade, etc. Furthermore, whenever officials and armies receiving and seeing off each other, they would assign a labor service to serfs, so serfs had to accept over 20 external labor items each year, and many serfs suffered from unimaginable torture during their service, even toiled to death. The other type of labor service was called "internal service", in which serfs had to plough "support land" for the three major seigniors, from sowing, hoeing, reaping to storing, which were completely undertaken by serfs with no obligation. There were also twenty or thirty types of internal labor items, such as "cutting grass", "twisting wool", "covering roofs", and "pasturing cattle", etc. Besides, there was also "conscript labor", and "building penstock", etc. Such various heavy labor services occupied two thirds or three quarters of annual time of serfs, and they had no choice but to suffer unspeakably. As for serfs who had no ability to accept a labor service, their owners enforced moneylending to them, or retook land, livestock and farm tools from them, which were then transferred to those serfs with the ability to accept a labor service. Therefore, quite a large number of "Khral-pas" either were in heavy debt, not able to pay off their serfowners for several decades, being their serfs for generations for repaying the debt, or were confiscated with land, soon reduced to "“"Dui-chun" or "Lang-sein".

The particular authority of the Law in old Tibet to protect occupation of serfs by serfowners, and "13-Article Code" as well as "16-Article Code" which passed for several hundred years, clearly stipulated unequal status of people before the Law, "the three major seigniors are the superior, who enjoy an absolute authority in terms of politics and economy, etc. The medium social class includes general monks and officials, military officers of lower level and button men fed by the three major seigniors. The lowest social level includes the extensive serfs and slaves, such as women, blacksmiths, butchers, and tramps, etc, who are at the bottommost social level, without any right. Humans can be classified as gentle and simple. With different social hierarchies, one's life value and price differs too. Life of humans is also different, the 
top people with a gentle life, and the lower people with a simple life. The King of Tibet is the superior seignior, with a priceless life. Officials, monks and chiefs are at the top hierarchy, so "price of their corpse can be measured by gold". Price of the life of those at the lowest level merely equals to a length of hayband, including tramps, blacksmiths, and butchers, etc.

Under such a system, serfs didn't have the most fundamental right of equal survival. They had to endure all inhumane treatment, struggle in a painful life, and suffer from great torture. A serf named Laba denounced, "All my ancestors were patrimonial blacksmiths, which was the lowest social class at that time, and they were called 'black bones'. They said our blood and bones were black, and whoever talked to us or drank a little of our water would have bad luck. Therefore, in those days, we always drifted about with a shabby tent. We worked if there was any and we begged if there wasn't, driven around just like tykes. I have a brother with the name of A Gui, who was smart and quick-witted when young. He was taken away by a seignior, who asked my brother to play with his monkeys, and to jump up and down with the real monkey so as to tickle him. The seignior called my brother "man monkey". In the season near the lunar calender in Tibet when was the coldest time during a year, just for pleasure, the seignior often threw my brother into a slot for washing "black bones". Drifting from the front gate of the manor to the back door, my brother was almost frozen to death when he was dragged out." This was the miserable experiences of serfs under the serf system, and this was the human right under the serf system.

Tibet is located on the roof the world, so there is little cultivatable land and pasturable grassland. Besides, it was seized by the three major seigniors, so material living conditions of Tibetan serfs were extremely primal, tousy and underprivileged. Under exploitation of serfowners, large quantities of serfs were frozen to death, starved to death, and even reduced to beggars. In 1951 when Tibet got liberated in a peaceful way and when the Liberation Army marched into Lhasa, thousands of beggars, prisoners, and cadavers and hordes of tykes were found everywhere. The south of Jokhang Temple was a beggar village called "Lu Bu Bang Cang", and surroundings of Ramoche Temple were assembly places of beggars. The number of beggars at that time almost reached over three to four thousand, which accounted for one tenth of population in the city. Thereby, the feudal serf system of Tibet was on the verge of collapse.

\section{Obstruction of the political system of "Constantinism" on social progress}

The fifth Article of "Universal Declaration of Human Rights" stipulated, "Excruciation was prohibited to any one, and also any infliction of cruel, inhumane or contumelious treatment or punishment". The ninth Article stipulated, "Arbitrary arrest, constraint or exile was prohibited to any one". However, under the savage and dark political system of "Constantinism" in old Tibet, it was absolutely impossible to realize this ideal goal which stands for social progress.

Since the Yuan Dynasty, the feudal political system of "Constantinism" has been formulated in Tibet, and a religious chief was simultaneously a political leader. By the period of Qing Dynasty, this political system has been quite complete and strict. All officials in each Ji-qia (equivalent to the current "District") and Zong (equivalent to the current "County") in local government and its subsidiary organs in old Tibet were jointly constituted by the top monks and lords, and Dalai Lama was the Chief representative. The essence of "Constantinism" was to imprison and keep under control the extensive serfs under the cover of thearchy and under the velarium of religion, to maintain feudal ruling order of Tibet, and to completely support the reign of the decayed, downfallen and cruel serfowners. On one hand, the religious power reigned the great number of people by its administrative power. On the other hand, it inflicted spiritual threat to people by its religious doctrines and in the name of awarding and punishing their otherworld. It is in this way that religious power and political power got closely combined.

The theory of causation in Buddhism is a significant theoretical basis of "Constantinism". The highest symbol of a ruler was the living Buddha, and he was considered a temporal idolater, an otherworldly rescuer, and a dominator of Body and Soul. And a secular ruler merely belonged to a ruling hierarchy of lower class with his support and under his command. According to the Buddhism doctrine, if one resisted his ruler, he not only wouldn't enjoy the "otherworldly" happiness after death, but his soul would be thrown into "Jigoku", tortured by all kinds of excruciation. He would not be excused from death forever, and even if he were finally "reincarnated", he would only be "a creature", and even wouldn't get his human body. Due to historical and regional reasons, and especially enforcement of rulers, Tibetan people all believed in Buddhism. The three major seigniors occupied a commanding position, ordered their serfs about in name of the Buddhist, and required them to take things as they were, and to endure economic exploitation and political oppression of serfowners so as to go for an illusory eternity Reincarnation. Under anesthesia of such a religious doctrine, serfs were forcibly indoctrinated various religious doctrines. Therefore, they thoroughly lost the rights of free thinking in a spiritual world. They had to follow the living Buddha. Otherwise, they would be guilty.

The top class monks in Tibet were totally engaged in all levels of political activities, and all their religious activities were served for political and economic interests of "the three major seigniors". All temples owned their land and serfs. According to the Law, monks needn't work, and all labours were imposed on serfs. Furthermore, expenditure of all large-scale religious activities should be burdened by serfs. The living Buddha, Lama, and high-ranking monks lived an affluent and even luxurious living all without exception, while those extensive impoverished serfs had to suffer from 
hardship and their suffering was unspeakable. Serfs were not allowed to resist this inhumane treatment, and all temples in Tibet had their loathsome instruments of torture. For instance, in Ganden Monastery, there were a great deal of handcuffs, fetters, clubs and instruments of torture for scooping out eyes, and drawing out tendons, etc. Monks and lords behaved their own way, such as feeding button men and hatchet men, personally setting up an illegal court and prison, undertaking all legal cases, abusing cruel punishment, arbitrarily arresting slaves and serfs, and arbitrarily beating and slaughtering them. However, all this wouldn't violate the law. The "Constantinism" enforced the extensive serfowners to endure unlimited cruel oppression and exploitation, which caused some serfs to go to the temple and join in the monks for alleviating burden of the corvee tax and for a way out as well as for depositum. However, even in the temple, they were still serfs, and the only difference was that they became serfs in cassock. At the same time, the old Tibetan local government forced serfs to be monks. For example, it was expressly stipulated that "One of them three men had to be a monk", which resulted in a large quantity of monks and nuns in Tibet. Before the democratic reform, 120 thousand were monks and nuns in approximately 1.2 million of population, which accounted for $10 \%$ of the entire population. They neither undertook material production, nor any population production. Therefore, the large quantity of labour force who should have created social wealth became parasites of the society, which seriously blocked development of the Tibetan social production capability, and caused economy of the feudal serf system to be overburdened.

By virtue of religious power, rulers of the old Tibet also brought about a relatively closed cultural environment, in which any new thought was prohibited. Any new thought or concept in violation with the religious doctrine, or in violation with interests and concepts of the three major seigniors would be regarded as heresy, and would be excluded and jugulated. Tibetan people had no choice but to accept religious thought, and they had no rights to accept any other education. This cultural absolutism seriously damaged a rational spirit, so the entire Tibetan society refused any progress or any modern civilization.

Serf system was a social system in place of the slavery in the history, and it had been followed for several hundred years. With development of the social production capability, this feudal serf system gradually became a shackle of social progress. Its imprisonment on personal freedom of laborers, its suppression and disparagement of human dignity of labors, and its deprivation of survival rights of laborers were resenting, and caused the surging "abolishment of serf system" worldwide. By the $19^{\text {th }}$ Century, the serf system had been a history in most countries and regions in the world. By 1950s, the feudal serf system in old Tibet had been out of tune with the historical development. it was the root of the impoverished and backward Tibet. Therefore, the extensive monks and people would always be in extreme misery and Tibet wouldn't step towards a civilized and progressive path without thorough reform and abolishment of the serf system.

At the moment when Tibet was faced with a historically radical change, those monks and especially high-ranking monks with religious authority, played a primary role in interfering social progress. They were clearly aware that a modern reform of the Tibet would equal to a downcome of the golden ages of old Tibetan "System of mass monks", and would equal to destruction of the "Constantinims". The new society wouldn't allow for continual existence of the parasitical hierarchy, for continual existence of the strongly fortified hierarchy, and for the continual existence of mutual oppression and enslaving. However, however they resisted, the step of social progress would be irresistible. The downfallen serf system hindered civilized progress of the society, so it would necessarily go extinct, which is an objective rule that can't be changed by any will. A social system that is more humanistic with humanism ideal would finally replace the dark, hideous, out-dated and inhuman society.

In 1959, when the Chinese government declared thorough abolishment of feudal serf system and a democratic reform in Tibet, millions of Tibetan serfs cheered at their liberation, singing and dancing. For the first time, they had their own land, and their own property. They finally became free, and had the rights of free labor and free living. They finally could enjoy their own labor fruit, and could dominate their destiny. Thence, the human rights condition in Tibet changed revolutionarily, and the human rights career in Tibet began its roaring development. And the new China thereby made a huge contribution to the human rights campaign in the world.

\section{References}

Du, Tai. (2004). Tibetan Changes I experienced, in Testimonio Cien Anos Del Tibet. Beijing: China intercontinental press, pp.2-10.

United Nations C2006. Universal Declaration of Human Rights. [Online] Available: United Nations Website: http;//www.un.org/chinese/hr/issue/udhr.htm, UN Webpage Affairs Division of United Nations Department of Public Information.

Xu, Ping. (2004). Self Report of Farmers in Bangjor Lhunbo village, In Testimonio Cien Anos Del Tibet. Beijing: China intercontinental press, p108; pp.104-112.

Ye, Lu \& He, Shi. (1991). Preliminary Analysis of Fedual Serf System in Tibet, in Selected Theses of Study on Feudal Serf System in Tibet. Beijing: China Zangxue Press, pp.81-101. 